\title{
Klasyk (częściowo) oswojony Kategoria analityczna roli chorego Talcotta Parsonsa i jej status we współczesnej socjologii medycyny
}

\section{Wstęp}

Status Talcotta Parsonsa jako „współczesnego klasyka” teorii socjologicznej uznać wypada za mocno ugruntowany. Zadecydował o tym nie tylko niezwykle wpływowy - jak się okazało - nurt funkcjonalizmu, którego Parsons stał się czołowym przedstawicielem, ale także (a może nawet przede wszystkim) kontrowersje, jakie wzbudziła jego autorska, niezwykle wyrafinowana - zarówno w formie, jak i treści - propozycja odpowiedzi na ciagle powracajace $\mathrm{w}$ teorii socjologicznej pytanie: jak możliwy jest ład społeczny? Zbudowany pieczołowicie przez Parsonsa gmach abstrakcyjnych pojęć, tworzący - w toku poszerzania przez uczonego horyzontu swych analitycznych zainteresowan - coraz ogólniejsza perspektywę badawcza (której punktem dojścia stać się miał osławiony koncept „systemu społecznego" jako metateorii społeczeństwa), stanowił nieodłaczny punkt odniesienia dla wielu innych badaczy - teoretyków, zarówno tych współczesnych Parsonsowi, jak i tworzących w późniejszych dekadach. Jak pisze A. W. Gouldner, jeden z naczelnych „krytycznych egzegetów” Parsonsa, „stwierdzenie, że prace Parsonsa sa intelektualnie istotne, nie oznacza rzecz jasna, że ma on rację. Jednak nawet kiedy jest $\mathrm{w}$ błędzie, (osobiście uważam, że myli się w fundamentalnych kwestiach), i nawet jeśli lekceważy pewne problemy, to zmusza nas to stawienia im czoła [...]. Nie ma dzisiaj ani jednego teoretyka akademickiego - z pewnością nie jest nim Homans ani Goffman - który byłby choć w połowie tak wpływowy lub miałby tak szerokie znaczenie teoretyczne jak Talcott Parsons. Pomimo, iż era jego dominacji dobiega końca $^{1}$, był i w dalszym ciagu jest kotwica intelektualną dla akademickiej

\footnotetext{
${ }^{1}$ Wywód ten odnieść należy do okresu, w którym Gouldner pisał niniejsze słowa - $1970 \mathrm{r}$.

To data publikacji jego głośnej pracy Kryzys zachodniej socjologii (wyd. pol. 2010).
} 
teorii socjologicznej we współczesnym świecie" (2010: 164). Jak wskazuje dalej Gouldner, szeroki rezonans, jakim cieszyła się perspektywa teoretyczna Parsonsa, stanowił nie tylko efekt samej jego (obfitej) twórczości, lecz także rezultat „pośrednictwa” jego studentów-wychowanków na Harvard University, takich jak R. K. Merton, K. Davis czy W. Moore (a także studentów z późniejszych czasów), którzy nie tylko mniej lub bardziej wiernie poruszali sie $\mathrm{w}$ paradygmacie teoretycznym swojego Mistrza, ale także z czasem stali się ważnymi przedstawicielami amerykańskiego establishmentu akademickiego i redaktorami prestiżowych naukowych czasopism. Jak stwierdza z pewnym przekasem Gouldner, „mam wrażenie, że - bardziej, niż w przypadku jakiejkolwiek innej współczesnej akademickiej teorii społecznej - teoria Parsonsa doszła do głosu dzięki tego rodzaju sieci zwolenników, którzy mieli własny interes w zdobyciu dla niej poparcia" (Gouldner 2010: 196). Gouldner nadmienia także o roli i specyfice samego miejsca pracy Parsonsa i jego uczniów powstałym w latach 30. XX w. Wydziale Socjologii na Harvardzie - które sprzyjać miało, jak to określa Gouldner, „teoretycznej brawurze”. Nowo powstały Wydział - nie obarczony ograniczajaca tradycja - otwarty był na intelektualne poszukiwania swoich wykładowców, a i sama uczelnia jako swoista „marka” stanowić miała instytucjonalne zaplecze wspomnianej brawury. Wejście w szeregi kadry miało być traktowane przez uczonych jako „stempel” potwierdzający słuszność i doniosłość obranej ścieżki teoretycznej/naukowej (Gouldner 2010: 169).

\section{Talcott Parsons jako Auguste Comte XX wieku}

Choć na przestrzeni dekad komentatorzy dorobku Parsonsa mieli się uciekać do - jak to określa J. C. Alexander (1991: 269 za Ziółkowski 2000: 74) - „krytycznej wulgaryzacji” jego koncepcji, od przełomu lat 70. i 80. XX w. obserwuje się stopniowa „rehabilitacje” funkcjonalizmu, w postaci rozwijanego na gruncie amerykańskim neofunkcjonalizmu (wspomniany Alexander), a także funkcjonalizmu systemowego (N. Luhmann). Zasadniczo jednak przeważa opinia o Parsonsie jako autorze trudnym w lekturze i zdradzającym „zapędy” megalomańskie. Ostrze krytyki formułowanej wobec teorii Parsonsa koncentruje się zasadniczo na dwóch powiązanych ze soba wątkach.

Pierwszy dotyczy dążeń Parsonsa do całościowej syntezy wszystkich poziomów analizy społecznej, zasadzającej się na próbie połączenia w jeden korpus teoretyczny swoich wczesnych zainteresowań - inspirowana Weberem - teoria działania (w jego własnej, „woluntarystycznej” wersji) z makropoziomowa teorią systemu społecznego, która rozwijał 
w późniejszym okresie. Zdaniem wielu komentatorów, owa próba integracji poziomu mikro i makro w jedną spójną całość nie była przekonujacca. I tak np., jak wskazuje G. Ritzer, „nie chodzi o to, że połączenie teorii działania $\mathrm{z}$ funkcjonalizmem strukturalnym jest niemożliwe lub niepożądane; po prostu Parsons nigdy ich odpowiednio ze sobą nie pogodził. W jego pracach często pojawiaja się obok siebie, zamiast się przeplatać" (2004: 295).

Z kolei drugi - powiązany jednakowoż z pierwszym - nurt krytyki, koncentruje się na kompulsywnej skłonności Parsonsa do konceptualizacji pojęć, co skłania Gouldnera (2010: 199) do określenia go mianem współczesnego wcielenia Comte’a. Owej manierze towarzyszy przy tym niebywała zawiłość stylu, co razem tworzy swoista „mieszankę wybuchową. Jak obrazowo stwierdza H. Białyszewski we wstępie do polskiego wydania zbioru artykułów amerykańskiego socjologa, ,[...] Parsonsowski teoretyczny las jest rozległy i gęsty, istna dżungla finezyjnych rozróżnień terminologicznych i zachodzących na siebie klasyfikacji, wysoki poziom abstrakcji, nizanie argumentu za argumentem bez jednoczesnego odwoływania się do królestwa faktów empirycznych, których argumenty te przypuszczalnie dotyczą" (1972: XLV). Przywoływany już kilkakrotnie Gouldner niestrudzenie próbuje w tym kontekście zrozumieć swoisty paradoks: jak to się stało, że tak zawikłane językowo wywody Parsonsa nie umniejszyły skali rezonansu jego teorii? Stawiajac osobliwa teze, iż uczony ów nie odczuwał chęci bycia zrozumianym przez innych, Gouldner (2010:195) wskazuje, że popularność Parsonsa może świadczyć o załamaniu się systemu kontroli społecznej, który w zwyczajowych warunkach sprawuje piecze nad twórczością uczonych. Powraca w tym miejscu do swojej hipotezy dotyczacej „efektu aureoli” wywieranego przez Harvard na prestiż zatrudnionych „u siebie” uczonych, którym było „więcej wolno”, jeśli chodzi o uprawianie nauki, także w kwestii klarowności języka, jakim posługiwali się w swych publikacjach. Pomimo całej swej krytyki, autor Kryzysu zachodniej socjologii potrafi przyznać, że „konceptualna retoryka" Parsonsa ma w sobie coś niebywale pociagającego w swym piętrowym zawikłaniu. Jak sam stwierdza, „[Parsons] był w stanie przywołać wizję czegoś szczególnego, systemu społecznego, i wywołać poczucie jego realności za pomoca środków majacych na dobra sprawe charakter czysto literacki [...]. Analiza Parsonsa daje socjologom poczucie namacalnej substancjalności pewnego szczególnego bytu, który przyjmują za przedmiot własnych, swoistych działań, co pomaga im w uzasadnieniu istnienia socjologii jako odrębnej dyscypliny" (Gouldner 2010: 206).

Dorobek piśmienniczy Parsonsa zasadniczo dzielony jest w sposób ogólny na „okres wczesny”, kiedy to uczony ów rozwijał swoją woluntarystyczna teorię działania (Parsons 1937) oraz „okres późniejszy”, 
w którym jego zainteresowania zaczęły oscylować wokół analizy funkcjonalnej, co swój najpełniejszy wyraz znalazło w opus magnum autora zatytułowanym System społeczny (1951; wyd. pol. 2009). Zaprezentowana periodyzacja nie oddaje jednak bogactwa zainteresowań Parsonsa - twórcy i kierownika (od 1947 r.) interdyscyplinarnego Wydziału Stosunków Społecznych na Harvardzie - rozciągajacych się od psychologii behawioralnej i klinicznej oraz psychiatrii, po nauki polityczne, antropologie i ekonomię. Parsonsowi przypisuje się autorstwo ponad setki artykułów traktujacych na różne tematy (Lidz 2007:33-65). Tytuły kilku wybranych z nich (Motywacja działalności gospodarczej, Spojrzenie socjologa na zawód prawnika, Demokracja a struktura społeczna $w$ przednazistowskich Niemczech) pozwalają uświadomić sobie ogrom zakresu jego analiz (Parsons 1972).

\section{Talcott Parsons jako socjolog medycyny (i niedoszły lekarz)}

Dla socjologów medycyny, czy też - patrząc szerzej - wszystkich badaczy, których zainteresowania zahaczaja o problematykę zdrowia i ogółu jego społecznych kontekstów, jako szczególnie istotne jawią sie analizy Parsonsa dotyczace - jak on sam to określa - „praktyki medycznej”. Z całą moca należy stwierdzić, iż wspomniany nurt badawczy nie stanowi jednak, jednego z wielu" podejmowanych przez Parsonsa. Wprost przeciwnie - należy go uznać za wytyczajacy w dużej mierze trajektorię znacznej części późniejszych, modelowych analiz dotyczących makroporządku społecznego. I tak np., Parsons deklarował, iż schemat osławionych zmiennych wzoru opracowany został pierwotnie właśnie w związku z badaniami nad praktyką medyczna, a ona sama „[...] stanowiła przedmiot długotrwałego zainteresowania autora, przez co ma on w niej większe rozeznanie niż w większości innych [dziedzin], ze względu na szerszą znajomość materiału empirycznego"2 (Parsons 2009: 319-320, Parsons 1969b: 401). Jak wskazuje M. Ziółkowski (2000: 68), swoje studia w Amherst College w stanie Massachusetts Parsons rozpoczać miał wręcz z intencją zrobienia kariery medycznej, co z pewnością wiązało się $\mathrm{w}$ jakiejś mierze $\mathrm{z}$ faktem, że miał brata lekarza cieszącego się uznaniem, a którego sam - jak pisze (Parsons 1969b: 398) - „uwielbiał”. Pierwszy krok ku karierze medycznej Parsonsa stanowił

\footnotetext{
${ }^{2}$ Dopowiedzieć warto, iż deklarowanymi przez Parsonsa technikami badawczymi były: przeprowadzone wśród lekarzy-praktyków obserwacje oraz wywiady poświęcone postrzeganiu przez nich wykonywanej przez siebie roli zawodowej (Parsons 1969b:400).
} 
wybór biologii jako kierunku studiów; z czasem jednak poświęcił się on naukom społecznym - ze szczególnym uwzględnieniem ekonomii - co nie zmienia faktu, że właśnie problematyce zawodu lekarza poświęcił wiele swoich prac (Ziółkowski 2000: 68). Z pewnością jako fundujace dla przyjętego przez Parsonsa schematu analitycznego uznać należy jego zetknięcie się z dwojgiem uczonych: Bronisławem Malinowskim, od którego (podczas rocznego pobytu na London School of Economics) uczyć się miał podejścia funkcjonalnego, oraz Lawrencem J. Hendersonem biochemikiem i psychologiem w jeden osobie, który w swym podejściu badawczym stosował ujęcie systemowe i podkreślał rolę homeostazy w funkcjonowaniu organizmów biologicznych (Ziółkowski 2000: 68-69; Twaddle 2007: 4318; Gallagher 2007: 33-75). Owo podejście systemowe Henderson odnosił także do relacji lekarz-pacjent. Sam Parsons inspirującej roli swego kolegi nie ukrywał i na pierwszej stronie rozdziału 10. swego Systemu społecznego - traktujaccego o praktyce medycznej odsyła on czytelnika do artykułu Hendersona (1935), „w celu ogólnego porównania z tym [10.] rozdziałem" (Parsons 2009: 319).

Patrząc z dzisiejszej perspektywy, trudno uwierzyć, iż to dopiero od Parsonsa datuje się systematyczne zainteresowanie medycyną ze strony socjologii. Jak wskazuje W. C. Cockerham, ,inaczej, niż w przypadku prawa, religii czy polityki, medycyna była pomijana jako instytucja społeczna przez założycieli socjologii $\mathrm{w}$ końcu dziewiętnastego wieku [...]" [tłum. - B. A.] (2001: 11 za Gallagher 2007: 33-75). Sam Parsons miał kilkakrotnie wyrażać swoja satysfakcje z powodu nadania mu etykiety ojca-założyciela socjologii medycyny, jednocześnie nie kryjąc z tego powodu pewnego zaskoczenia (Gallagher 2007: 33-75; zob. deklaracja samego Parsonsa w tej materii: Parsons 1969b: 397). Jego podstawowy wkład we wspomnianym obszarze stanowi analityczna kategoria roli chorego oraz - związana z nią - konceptualizacja diadycznej relacji łączaccej owego chorego (pacjenta) z lekarzem. Zarówno pierwsza, jak i druga uznawane sa za „kamienie węgielne” socjologii medycyny, bez których żadne kompetentne omówienie tej subdyscypliny nie może się obejść. W dalszej części artykułu uwaga autora skoncentruje się na szczegółowym omówieniu zarówno kategorii roli chorego, jak i relacji lekarz-pacjent.

Jak wskazuje E. Gallagher (2007: 33-75), Parsons nie był pierwszym uczonym akademickim, który zgłębiał problem relacji łączącej pacjenta i lekarza. Gallagher wymienia w tym kontekście - wspomnianego już wcześniej - Hendersona, a także historyka medycyny P. Lain Entralgo oraz niemieckiego uczonego Rudolfa Virchowa. Wskazuje on jednocześnie, że analizom wymienionych badaczy brakowało analitycznego rygoru i ujęcia stricte socjologicznego, które ujawniły się dopiero w podejściu Parsonsa. Stosunek lekarz-pacjent Gallagher proponuje 
określić najogólniej jako specyficzną odmianę relacji pomagania, w której jedna ze stron (chory) może „czerpać korzyści” określonego rodzaju $\mathrm{z}$ uwagi na fakt, że druga strona tej relacji (lekarz) to podmiot będacy w posiadaniu pewnych „zasobów”, w postaci swojej wiedzy fachowej, umiejętności i doświadczenia. Przy czym chory-,,potrzebujący” ufnie zakłada, że dla jego dobra lekarz wykorzysta wspomniane zdolności najlepiej, jak tylko potrafi. O roli lekarza Parsons pisze, iż „[...] należy [ona] do ogólnej klasy ról «profesjonalnych», podklasy szerszej grupy ról zawodowych. Opieka nad chorym nie jest bowiem poboczną działalnością w ramach innych ról - choć na przykład matki wykonuja sporą jej część - lecz stała się funkcjonalną specjalizacja jako «pełnoetatowa» praca [...]. Jako rola zawodowa, rola lekarza zorganizowana jest wokół technicznej treści funkcji, która cieszy się znacznym stopniem nadrzędności względem innych czynników statusu. Nieuchronnie rola ta musi być osiągana, a kryteria prawidłowego jej wypełniania muszą być zgodne z jawnymi standardami technicznymi” (2009: 323). W propozycji Parsonsa wspomniana relacja - odznaczajaca się „profesjonalnym” charakterem (wedle samych jego słów będąca „neutralna afektywnie”) - ma pewne cechy zbieżne $\mathrm{z}$ relacją rodzic-dziecko (w której to drugie także odznacza się ufnością), choć relacja ta różni się od relacji lekarz-pacjent zakresem, czasem trwania i stopniem (jest „afektywnie zaangażowana”) ${ }^{3}$. Zaprojektowany w taki, a nie inny sposób „kształt” relacji lekarz-pacjent niesie z soba określone konsekwencje. Jak pisze Parsons, „określając wzór roli osoby chorej jako potrzebującej pomocy i wymagając od niej nawiązania kontaktu z czynnikami terapeutycznymi, uzależniamy chorego od osób nie chorych" (1969a: 343).

O ile przykład roli lekarza jako „odsłony” roli zawodowej - czy też sprofesjonalizowanej roli społecznej - nie stanowi novum na gruncie socjologii, o tyle bycie pacjentem/chorym, potraktowane także w kategoriach roli społecznej „do odegrania/wypełnienia”, stanowi bez wątpienia prekursorską (i tym samym mogąca budzić pewne zastrzeżenia) propozycję analityczna. Sam uczony miał zresztą tego świadomość. Jak bowiem pisze, „[...] w kategoriach zdrowego rozsądku można podnieść wattpliwości, czy «bycie chorym» stanowi rolę społeczna - czyż nie jest to po prostu stan faktyczny, «uwarunkowanie»? Sprawy nie przedstawiaja się jednak aż tak prosto. Sprawdzianem jest istnienie zbioru

\footnotetext{
${ }^{3}$ Koncepcja Parsonsa naznaczona jest licznymi wpływami psychoanalizy i związanej z nią siatki pojęciowej, czego najlepszy dowód stanowią teksty zamieszczone w pierwszej części jego pracy Struktura spoteczna a osobowość (Parsons 1969c), takie jak: Superego a teoria systemów społecznych, Symbol ojca. Ocena w świetle teorii psychoanalitycznej $i$ socjologicznej, czy też Struktura społeczna a rozwój osobowości: wktad Freuda w integracje psychologii i socjologii.
} 
zinstytucjonalizowanych oczekiwań oraz odpowiadajacych im uczuć i sankcji" (Parsons 2009: 325).

Podsumowując: propozycja analityczna Parsonsa w omawianym tutaj obszarze zasadza się na „obdzieleniu” obu stron wspomnianej relacji - pacjenta i lekarza, ujmowanych w kategoriach ról społecznych, zarówno pewnymi obowiązkami, jak i przywilejami. Jak stwierdza sam Parsons, „bezpośrednio istotne struktury społeczne to uwzorowanie roli samego lekarza praktyka i, choć może się to wydawać przesada, rola samej osoby chorej. Obie role wpływają też na wiele różnych sposobów na inne aspekty całościowej struktury systemu społecznego [...]" (Parsons 2009: 323). Zanim zaprezentowane zostana osławione zinstytucjonalizowane oczekiwania formułowane „pod adresem” osób definiowanych jako chore (które to oczekiwania innymi słowy określić by można mianem społecznie akceptowanych sposobów zachowania się w chorobie), warto wspomnieć o szerszym kontekście dokonywanych przez Parsonsa analiz w tym zakresie.

Po pierwsze, koniecznymjest wspomnieć, iż kategoria analityczna roli chorego jest częścią ogólniejszej teorii działania społecznego (wzmiankowanej na początku niniejszego artykułu). Konsekwencją przyjętej przez Parsonsa funkcjonalnej normy zdrowia definiowanego jako stan, w którym jednostka wykazuje optymalną umiejętność efektywnego pełnienia ról, jest przypisanie praktyce medycznej funkcji regulatora „[...] systemu społecznego pozwalającym radzić sobie z chorobami jego członków" (Parsons 2009: 321). Chodziło o to, aby wobec różnorodności ludzkich zachowań zasługujących na miano dewiacji społecznej (a więc stanowiących odchylenie od obowiąujacych norm społecznych) móc wyodrębnić te, które zasługują na miano choroby (i tym samym wymagają leczenia) oraz te, które winny być uznane za przestępstwo (i zostać ukarane). Warto podkreślić raz jeszcze, że jedyną instancją władną dokonywać owych „rozróżnień” jest medycyna. Parsons wyraźnie oddziela dwie kategorie: wymiar dewiacji społecznej (dotyczący niezamierzonych przez jednostkę skutków jej działań) i wymiar kontroli społecznej (dotyczacy umyślnego nieprzestrzegania norm). Jak sam wskazuje, ,jeśli bycie chorym ma być uważane za «dewiację», a z pewnościa pod pewnymi względami powinno być tak traktowane, to, jak zauważyliśmy, odróżnia się ono od innych ról dewiacyjnych właśnie przez fakt, że osoby chorej nie uważa się za «odpowiedzialną» za swój stan, nie może ona nań nic «poradzić»" (Parsons 2009: 327). Innymi słowy, traktuje on chorobę i przestępstwo jako alternatywne formy dewiacji społecznej, leczenie i karanie jako alternatywne reakcje/„odpowiedzi” na owa dewiacje, zaś - na najogólniejszym poziomie - system opieki medycznej oraz system wymiaru sprawiedliwości jako alternatywne systemy kontroli społecznej (Twaddle 2007: 
4318). Koniecznym jest pamiętać, że nie tyle o zdrowie jednostki jako konkretnego indywiduum przede wszystkim tutaj chodzi. Dla Parsonsa bowiem „,...] problem zdrowia jest ściśle związany z funkcjonalnymi wymogami [...] systemu społecznego. [...] nie ulega watpliwości, że istnieje społeczny interes funkcjonalny w jego [zdrowia - rozumianego jako efektywne pełnienie ról] kontroli, a szerzej, w minimalizacji choroby"4 (Parsons 2009: 320). Zdrowie ujęte zostaje więc tutaj w kategorii „potencjału funkcjonalnego" i stanowi swoisty wymóg przetrwania społeczeństwa. Dlatego też system profesjonalnej opieki medycznej winien odgrywać rolę - używając pojęcia już zupełnie spoza siatki pojęciowej Parsonsa - „psa stróżującego”, oferującego chorym zinstytucjonalizowane sposoby powrotu do zdrowia. Jak wskazuje Parsons, „kluczowym elementem jest tutaj [...] izolacja osoby chorej od pewnych rodzajów wzajemnego kontaktu z tymi, którzy chorzy nie sa, i od innych chorych. Najważniejszym powodem tej izolacji nie jest potrzeba ze strony osoby chorej jakiejś specjalnej «opieki», lecz fakt, że choroba bywa zaraźliwa zarówno motywacyjnie, jak i bakteriologicznie [...]. Uniemożliwia się więc choremu dawanie złego przykładu, który mógłby skusić innych" (1969a: 342-343).

Anonsowane już wcześniej instytucjonalne oczekiwania kierowane „pod adresem” chorego (zwyczajowo nazywane przez komentatorów koncepcji Parsonsa „cechami”/wyznacznikami roli chorego) prezentuja się następująco (Parsons 2009: 325):

1) choroba stanowi podstawę do zwolnienia jednostki z konieczności pełnienia przez nią zwyczajowych ról społecznych; przy czym najczęściej to lekarz-profesjonalista stanowi tu podmiot legitymizujacy wspomniany stan i ostateczną instancje odwoławcza;

\footnotetext{
${ }^{4}$ Podkreślanie przez Parsonsa znaczenia „społecznego interesu” w minimalizacji choroby i jej skutków owocuje niekiedy formułowaniem przez niego dość osobliwych wywodów. Za przykład niech posłuży następujący passus: „Jednym ze szczegółowych aspektów, na który możemy tu zwrócić uwage, jest przedwczesna śmierć. Z wielu punktów widzenia, narodziny i opieka nad dzieckiem stanowią «koszt» społeczny ze względu na ciążę, konieczność opieki, socjalizację, trening formalny i wiele innych form aktywności. Przedwczesna śmierć, następująca zanim indywiduum miało okazję do odegrania pełnego zakresu swych ról społecznych, oznacza, że nastąpił jedynie częściowy «zwrot» tego kosztu" (Parsons 2009: 320).

${ }^{5}$ Wymóg odseparowania chorego od nie-chorych, w świetle innego fragmentu wywodów Parsonsa, jawi się jeszcze dobitniej: „Życie stało się [początek XX w., realia amerykańskie - por. dalsze wywody w tekście głównym] bardziej skomplikowane i stawia ono jednostkę w obliczu dużo wyższych niż poprzednio wymagań [...]. Problemem staje się niekiedy zdobycie umiejętności tak wysokich, by tym wymaganiom sprostać. Wzrasta też motywacja do wycofywania się poprzez choroby psychiczne lub psychosomatyczne, nabierają też znaczenia mechanizmy naśladowania tych, którzy już tak uczynili” (Parsons 1969a: 348).
} 
2) chory nie ponosi odpowiedzialności za stan, w którym się znajduje; sama jego wola wyzdrowienia nie gwarantuje jednak powrotu do zdrowia i potrzebuje on „opieki” w postaci fachowych zabiegów terapeutycznych;

3) chory winien uznać stan, w którym się znajduje za niepożądany i wymagający podjęcia działań ku powrotowi do zdrowia;

4) chory ma obowiązek szukania kompetentnej pomocy (najczęściej w osobie samego lekarza) i współpracy z nim w celu doprowadzenia do wyzdrowienia. Jak pisze Parsons, „to właśnie w tym miejscu rola chorego formułowana jest wraz z rolą lekarza w ramach komplementarnej struktury ról” (Parsons 2009: 325).

Powyższe zestawienie zasługuje na co najmniej jedno dopowiedzenie. Otóż w licznych omówieniach wspomnianej „typologii” mowa zwykle wprost o lekarzu jako jedynej „instancji” uprawnionej do udzielania fachowej pomocy medycznej. Pozostaje to $\mathrm{w}$ zgodzie $\mathrm{z}$ biomedycznym paradygmatem zdrowia, właściwym okresowi, w którym tworzył Parsons. Sam uczony nie wskazuje jednak w sposób jednoznaczny na osobe lekarza. Pojawiajace się ogólne hasło zapewnienia choremu swoiście rozumianej „opieki” (por. punkt 2) oraz wskazanie na konieczność poszukiwania kompetentnej pomocy najczęściej - a za zatem nie bezwyjątkowo - ze strony lekarza (por. punkt 4) każą zrewidować obiegowy zasób informacji w zakresie omawianego tu wyliczenia. Jako że do czasu publikacji polskiego przekładu Systemu społecznego (Parsons 2009) polscy badacze w większości polegać musieli na omówieniach „z drugiej ręki" - nie licząc okrojonych fragmentów dotyczących roli chorego zawartych we wczesnym polskim przekładzie esejów Parsonsa (Parsons 1969a, 1969b) - sytuację tę można po części usprawiedliwić. Jak wskazuje A.W. Twaddle (2007: 4317), w kontekście zapewnienia choremu opieki Parsons używa zwykle pojęcia competent treatment agent (nie zaś physician - lekarz), choć Twaddle wskazuje jednocześnie, że według Parsonsa lekarz to zarazem najczęstszy przypadek owego „agenta opieki”6. Bez odpowiedzi pozostaje pytanie, kogo jeszcze - poza lekarzem Parsons zaliczał do stworzonej przez siebie owej ogólniejszej kategorii.

Wskazuje się, że kategoria roli chorego w ujęciu Parsonsa przez co najmniej trzy dekady (lata 1950-1980) stała się centralnym obszarem zainteresowań wszystkich badaczy społecznych zgłębiających obszar opieki medycznej (Twaddle 2007: 4317). Dopowiedzieć należy, iż stanowiła ona także inspirujacy bodziec do dalszego rozwoju socjologii

\footnotetext{
${ }^{6}$ Za dowód posłużyć moga słowa samego Parsonsa, który stwierdza, iż na chorym spoczywa obowiązek „[...] poszukiwania kompetentnej technicznie pomocy, a mianowicie, najczęściej, pomocy lekarza [...]” (2009: 325).
} 
medycyny jako wyodrębnionej dyscypliny. Inna sprawa, że wszelkie konceptualizacje „bycia chorym”, formułowane przez rozmaitych autorów tworzących w późniejszym okresie, zwykle krytycznie odnosiły sie do propozycji analitycznej Parsonsa, zarzucając jej zwykle zbyt waski zakres znaczeniowy. Najczęściej stawiane zarzuty dotyczą:

- ujmowania choroby wyłacznie w kategoriach obiektywnych, jako stwierdzonego przez lekarza zaburzenia funkcjonowania jakiegoś narządu lub części ciała (ang. disease), przy pomijaniu subiektywnego postrzegania stanu swojego zdrowia przez chorego w kategoriach dyskomfortu (ang. illness);

- nieadekwatności propozycji Parsonsa w przypadku chorób przewlekłych i/lub nieuleczalnych, gdzie wymóg „chęci powrotu do zdrowia" ze strony chorego staje się bezprzedmiotowy. Jako ciekawostke - a jednocześnie istotny kontekst dla powyższego - potraktować należy informację, iż u samego Parsonsa zdiagnozować miano cukrzycę (chorobe przewlekła), co w szczególnym świetle stawia tak, a nie inaczej „zaprojektowane” kryteria roli chorego (Twaddle 2007: 4318);

- nieadekwatności w przypadku chorób „obciążonych” piętnem społecznym, takich jak uzależnienia, niektóre ostre choroby psychiczne czy też choroby przenoszone droga płciowa, gdzie trudno niekiedy mówić o braku odpowiedzialności za stan, w którym jednostka się znalazła;

- nieadekwatności w przypadku stanów chorobowych bez większego znaczenia, jak np. zwykłego, krótkotrwałego przeziębienia, wobec którego „poważnie brzmiące”, wymienione wyżej cztery „oczekiwania" (a zwłaszcza zawieszenie zwyczajowych ról społecznych) wydają się nie na miejscu (a i, przykładowo, sam katar może minąć szybciej, niż chory zdoła skontaktować się z lekarzem);

- braku odpowiedniości dla różnych typów schorzeń ujmowanych w kategoriach chorób „usankcjonowanych” społecznie (brak „winy” jednostki), a jednocześnie ciagle nawracających lub też utrzymujacych sie stale, gdzie o „wejściu na ścieżke powrotu do zdrowia” trudno mówić. Przykład stanowić ma tutaj np. opóźnienie umysłowe lub też bycie „chorowitkiem” w rozumieniu ogólnej słabowitości i stałej tendencji do chorowania (Twaddle 2007).

Jak się wydaje, w tle formułowanych wobec koncepcji roli chorego Parsonsa zastrzeżeń widnieje jeden, wspólny rdzeń, mianowicie przypisywanie zbyt dużej roli profesji lekarza i instytucjom medycznym w ogólności i tym samym wywodzenie roli chorego z perspektywy roli lekarza. W sposób nieco bardziej uporządkowany problem ten przedstawić można w sposób następujący. 
Po pierwsze, jest przecież tak, że wiele schorzeń nie jest konsultowanych z lekarzem i „chorowanie” przebiega niekiedy zupełnie poza obszarem służby zdrowia jako instytucji (casus samoleczenia, korzystanie z medycyny alternatywnej). Po drugie, zaproponowany przez Parsonsa model relacji lekarz-pacjent nie uwzględnia - bo nie może, jako że sformułowany został w ramach wczesnego, biomedycznego paradygmatu myślenia o zdrowiu - postępującej złożoności współczesnej medycyny i jej społecznych kontekstów. „Prostoduszny” obraz relacji łączacej „typowego" pacjenta pozostajacego pod opieką lekarza rodzinnego abstrahuje zarówno od wyłonienia się na przestrzeni dekad wąskich specjalizacji medycznych oraz dynamicznego postępu naukowego w medycynie, jak również od bardziej pogłębionego, krytycznego namysłu nad wpływem na proces leczenia takich uwarunkowań, jak np. rosnace lawinowo koszty opieki zdrowotnej, administracyjna niewydolność, czy też interesy korporacyjne lekarzy i szpitali (Gallagher 2007: 33-76). Po trzecie, postępujący wzrost wiedzy medycznej samych pacjentów, pojawienie się organizacji reprezentujących ich interesy, a także uchwalenie licznych dokumentów (także w wymiarze międzynarodowym) gwarantujących im podstawowe prawa, wymusiło odejście od modelu zasadzającego się na asymetrii ról oraz paternalistycznego schematu „lekarz mówi - pacjent słucha" na rzecz bardziej otwartej komunikacji. Tym samym zaczęto uwzględniać podmiotowość i sprawstwo samego pacjenta jako współdecydującego o procesie leczenia, zwłaszcza w przypadku chorób przewlekłych, w leczeniu których „wkład własny” pacjenta odgrywa istotna rolę. Poza wszystkim, koncepcja Parsonsa - wskazuja komentatorzy - zdaje się zarazem zupełnie pomijać fakt, iż nie wszystkie jednostki w jednakowym stopniu wykazuja tendencję do uznawania siebie za chorego i zawieszania zwyczajowo pełnionych ról. Kolejność bywa niekiedy wręcz odwrotna: kontakt z lekarzem i „uznanie” choroby następuje wówczas, gdy odczuwane dolegliwości utrudniają codzienne funkcjonowanie.

Idąc jeszcze dalej, wskazać można na - dokonywany przez jednostkę (niekiedy w sposób nie do końca uświadomiony) - proces swoistego bilansowania strat i korzyści związanych z rola chorego. Sam Parsons wskazuje zresztą, iż „choroba może być traktowana jako jeden ze sposobów odpowiedzi na presje społeczne, jako sposób ominięcia odpowiedzialności społecznych" (2009: 321). Gratyfikacje o charakterze materialnym (przyznanie renty, wypłata odszkodowania) i/lub niematerialnym (współczucie najbliższego otoczenia) oraz sam „nagradzający” wymiar uzyskania statusu osoby chorej, pozwalajacy niekiedy jednostce uniknąć poważnych konsekwencji swoich działań (status osoby niepoczytalnej wpływający na nałożony wymiar kary sądowej lub też zwolnienie 
lekarskie jako usprawiedliwienie nieobecności na egzaminie) - wszystko to stanowi swoista „pulę” opcji, spośród których jednostka może wybierać najbardziej jej odpowiadająca (Taranowicz 2002: 77-78). Także Parsons zauważał, iż „przywileje i zwolnienia związane z rolą chorego moga stać się obiektami „wtórnych zysków”, do których zabezpieczenia lub czerpania pacjent jest - zwykle nieświadomie - pozytywnie umotywowany. Toteż pierwszorzędny staje się problem równowagi motywacji do wyzdrowienia. Ogólnie rzecz biorąc, równoważenia motywacyjne o dużym znaczeniu funkcjonalnym dla systemu społecznego są kontrolowane instytucjonalnie, nie powinien zatem dziwić fakt, że nie ma tu wyjątków" (2009: 325-326). Wskazuje się również na - pomijany przez Parsonsa - fakt, iż zróżnicowana tendencja do „wchodzenia” w rolę chorego uwarunkowana jest także czynnikami o charakterze kulturowym (np. wartość przypisywana zdrowiu, męskie wzorce „twardziela”, którego „choroba się nie ima”), religijnym (Tobiasz-Adamczyk 2000: 57-66), strukturalnym (np. dostępność opieki zdrowotnej, charakter kontaktów chory - personel medyczny), jak i osobowościowym (casus pracoholika, który „nie ma czasu chorować”) (Taranowicz 2002: 76).

Sam Parsons miał deklarować, że zaproponowany przez niego funkcjonalny (a zarazem normatywny) model relacji lekarz-pacjent, zasadzający się na ich wzajemnej, zgodnej współpracy w procesie zdrowienia tego drugiego, jest pewna otwarta propozycja analityczna, która nie rości sobie pretensji do uniwersalności. Pojawiające się „w odpowiedzi” liczne alternatywne konceptualizacje (m.in. funkcjonalny model T. Szasza i M. Hollendra, konfliktowy model E. Freidsona, transakcyjny model S. Blooma) w sposób mniej lub bardziej radykalny zrywały z podejściem Parsonsa, dodajac nowe akcenty i proponując odmienne perspektywy (Ostrowska 2009). Świadczy to tylko o tym, iż koncepcja Parsonsa zasługuje na miano nie tylko „otwartej”, ale i inspirujaccej. Poza wszystkim, o prostym przenoszeniu w skali „1 do 1” ujęcia Parsonsa w obecne realia nie sposób omówić, z co najmniej dwóch względów.

Po pierwsze, nie wolno zapominać, iż „nowoczesna praktyka medyczna” interesowała Parsonsa "w świetle amerykańskiego systemu wartości i struktury społecznej" (Parsons 1969a) i analizowana była w konkretnym momencie czasowym (lata 30. i 40. XX wieku). Jak pisze uczony, „w systemie amerykańskim szczególną role pełnią kolektywy, na przykład przedsiębiorstwa, i ich osiagnnięcia. Ostatecznie jednak wszystkie ich osiagnięcia zależą od umiejętności i zaangażowania jednostek ludzkich, pełniacych swe role i wykonujaccych zadania. W tym właśnie kontekście widać wagę oceny zdrowia. Centralnym punktem oceny jednostki jest uniwersalistycznie pojmowane osiaganie sukcesów [...]. Zdrowie zaś jest tak istotnym warunkiem sukcesu, że samo w sobie 
uznane zostało za cenioną wartość" (Parsons 1969a: 345-346). Jako że orientacja na sukces nie ma (nie musi mieć) charakteru uniwersalnego - podobnie zreszta jak traktowanie zdrowia jako wartości samej w sobie - to ostatnie traktowane jako „funkcjonalny wymóg” społeczeństwa jawi się jako element konceptualizacji „skrojonej” zdecydowanie na „amerykańską miarę”. Po drugie, jak wspomniano na samym początku, zainteresowanie relacją lekarz-pacjent i konceptualizacja roli chorego stanowiły - jak wszystko, co Parsons rozwijał na gruncie naukowym element szeroko zakrojonej teorii społecznej, w której na plan pierwszy wybijał się imperatyw „współzależności”, „funkcjonalności” i „systemowości”. Z pewnością z tym należy wiązać nacisk na komplementarność ról pacjenta i lekarza oraz ujęcie roli chorego w kategoriach zinstytucjonalizowanej roli społecznej, w ramach której jednostka ma dążyć do jak najszybszego powrotu do zdrowia, czyli - patrząc szerszej - do „stanu równowagi systemu". Koncepcje Parsonsa z obszaru socjologii medycyny, niejako zmuszeni jesteśmy przyjmować „z dobrodziejstwem inwentarza”, szerszej perspektywy teoretycznej, w ramach której zostały sformułowane ${ }^{7}$.

\section{Podsumowanie}

W ścisłym nawiązaniu do pierwszego zdania wstępu do niniejszego artykułu można powiedzieć, iż status Talcotta Parsonsa jako klasyka socjologii medycyny jawi sie jako kwestia poza dyskusją. Jego konceptualizacja roli chorego i wypracowany model relacji lekarz-pacjent stanowią dla kolejnego już pokolenia autorów punkt wyjścia do formułowania własnych propozycji analitycznych. Czy inspiracje na tak zakreślonym obszarze się wyczerpują? Niekoniecznie. Warto nadmienić także o innych.

I tak np., przyjęcie przez Parsonsa funkcjonalnej definicji zdrowia i ujmowania choroby w kategoriach łamania obowiązujących norm (niewywiazywanie się z ról) okazało się atrakcyjne dla wielu innych badaczy (niekoniecznie z obszaru socjologii medycyny) definiujacych chorobe w kategoriach dewiacji społecznej. Mowa zwłaszcza o tych z nich, którzy

\footnotetext{
${ }^{7}$ Wypada chyba zgodzić się z Gouldnerem, który stwierdza, iż „[...] Parsons uważa, że nie można poznać żadnego aspektu świata społecznego, dopóki nie umiejscowi się go w ramach całości [...]. Za mnożeniem charakterystyk poszczególnych części i ich wzajemnych relacji kryje się u Parsonsa dążenie do powiązania wszystkich składników w ramach całości, przy czym nic nie powinno pozostawać bez przypisanego sobie miejsca" (2010: 202).
} 
rozwijali teorie naznaczania społecznego (zob. Becker 2009; Synowiec-Piłat 2002). Poza tym, z racji tego, że Parsons zdrowie i chorobę definiował $\mathrm{w}$ oparciu o wymiar społecznego funkcjonowania jednostki, za inspirujacy walor jego koncepcji roli chorego uznaje się otwarcie drogi ku skonstruowaniu socjomedycznych wskaźników stanu zdrowia (zwłaszcza dotyczących osób starszych), a opierających się na kryteriach sprawności społecznej (np. samodzielne ubieranie sie, mycie, przygotowanie posiłków) (zob. Tobiasz-Adamczyk 2000: 44-56).

Jak więc widać, Parsons - teoretyk par excellence - stanowić może inspirację także dla bardziej praktycznych analiz, spoza mocno wyeksploatowanego nurtu rozważań nad rolą chorego i relacją lekarz-pacjent. Także i to można potraktować jako swoisty dowód na ciagła żywotność i doniosłość podejmowanych przez niego analiz.

\section{Bibliografia}

Alexander J. C. (1991), Neofunctionalism and Modern Sociology, [w:] Etkowitz H., Glassman R. (eds), The Renascence of Sociological Theory, Itasca, Illinois.

Becker H. S. (2009), Outsiderzy. Studia z socjologii dewiacji, PWN, Warszawa.

Białyszewski H. (1972), Wstęp do wydania polskiego, [w:] T. Parsons, Szkice z teorii socjologicznej, PWN, Warszawa.

Cockerham W. C. (2001), Medical Sociology ( ${ }^{\text {th }}$ edition), Prentice Hall-Upper Saddle River, New Jersey.

Gallagher E. (2007), Patient-physician relationhip, [w:] Ritzer G. (eds), The Blackwell Encyclopedia of Sociology, vol. VII, Blackwell Publishing, Malden-Oxford-Carlton.

Gouldner A. W. (2010), Kryzys zachodniej socjologii, Zakład Wydawniczy Nomos, Kraków.

Henderson L. J. (1935), Physician and Patient as a Social System, „New England Journal of Medicine", no 2.

Lidz V. (2007), Parsons Talcott, [w:] G. Ritzer (eds), The Blackwell Encyclopedia of Sociology, vol. VII, Blackwell Publishing, Malden-Oxford-Carlton.

Ostrowska A. (2009), Modele relacji pacjent-lekarz, [w:] Ostrowska A. (red.), Socjologia medycyny. Podejmowane problemy, kategorie analizy, Wyd. IFiS PAN, Warszawa.

Parsons T. (1937), The Structure of Social Action. A Study in Social Theory with Special Reference to a Group of Recent European Writers, The Free Press, New York.

Parsons T. (1951), The Social System, The Free Press, New York.

Parsons T. (1969a), Definicje zdrowia i choroby w świetle amerykańskiego systemu wartości i struktury społecznej, [w:] tenże, Struktura społeczna a osobowość, PWE, Warszawa.

Parsons T. (1969b), Kilka uwag $w$ sprawie socjologii medycyny, [w:] tenże, Struktura spoteczna a osobowość, PWE, Warszawa.

Parsons T. (1969c), Struktura społeczna a osobowość, PWE, Warszawa.

Parsons T. (1972), Szkice z teorii socjologicznej, PWN, Warszawa.

Parsons T. (2009), System spoteczny, Zakład Wydawniczy Nomos, Kraków.

Ritzer G. (2004), Klasyczna teoria socjologiczna, Zysk i S-ka, Poznań. 
Synowiec-Piłat M. (2002), Choroba jako rodzaj dewiacji społecznej, [w:] J. Barański, W. Piatkowski (red.), Zdrowie i choroba. Wybrane problemy socjologii medycyny, Oficyna Wydawnicza Atut, Wrocław.

Taranowicz I. (2002), Rola społeczna chorego, [w:] J. Barański, W. Piątkowski (red.), Zdrowie $i$ choroba. Wybrane problemy socjologii medycyny, Oficyna Wydawnicza Atut, Wrocław.

Tobiasz-Adamczyk B. (2000), Wybrane elementy socjologii zdrowia i choroby, Wydawnictwo Uniwersytetu Jagiellońskiego, Kraków.

Twaddle A. C. (2007), Sick role, [w:] G. Ritzer (ed.), The Blackwell Encyclopedia of Sociology, vol. IX, Blackwell Publishing, Malden-Oxford-Carlton.

Ziółkowski M. (2000), Parsons Talcott, [w:] H. Domański i in. (red.), Encyklopedia Socjologii, t. 3, Oficyna Naukowa, Warszawa.

\section{Classic (partly) acquired. Analytic category of sick role by Talcott Parsons and its status in contemporary sociology of medicine}

In his article the author presents briefly a part of theoretical output of classic sociologist Talcott Parsons, which is his pioneer contribution to sociology of medicine development. Author of article concentrates his attention on two related issues, which are the reference to various analysis taken from different theoretical perspectives, till the present day: Parsons' conception of sick role and his author's model of patient-physician relationship, flowing from, characteristic of him, functionalist paradigm.

The presentation also deals with critical opinions expressed towards mentioned conceptions and puts a question about their usefulness in contemporary sociology of medicine. According to author of article, issues related to social contexts of medicine need to be recognized as the clearest expounded in all Parsons' theoretical output, what makes it so popular beyond the same sociology.

Key words: Talcott Parsons, sick role, patient-physician relationship, biomedical model of health, functionalism. 